\title{
NLP-12 Engages Different UNC-13 Proteins to Potentiate Tonic and Evoked Release
}

\author{
Dithitao Hu, ${ }^{1,2}$ Amy B. Vashlishan-Murray, ${ }^{1,2,3}$ and Joshua M. Kaplan ${ }^{1,2}$ \\ ${ }^{1}$ Department of Molecular Biology, Massachusetts General Hospital, Boston, Massachusetts 02114, 2Department of Neurobiology, Harvard Medical School, \\ Boston, Massachusetts 02115, and ${ }^{3}$ Department of Communication Sciences and Disorders, Emerson College, Boston, Massachusetts 02116
}

A neuropeptide (NLP-12) and its receptor (CKR-2) potentiate tonic and evoked ACh release at Caenorhabditis elegans neuromuscular junctions. Increased evoked release is mediated by a presynaptic pathway (egl-30 G $\alpha_{\mathrm{q}}$ and egl-8 PLC $\beta$ ) that produces DAG, and by DAG binding to short and long UNC-13 proteins. Potentiation of tonic ACh release persists in mutants deficient for egl-30 G $\alpha_{\mathrm{q}}$ and $e g l-8$ PLC $\beta$ and requires DAG binding to UNC-13L (but not UNC-13S). Thus, NLP-12 adjusts tonic and evoked release by distinct mechanisms.

Key words: C. elegans; CCK; Munc13; neuropeptide; NLP-12; UNC-13

\section{Introduction}

To become fusion competent, synaptic vesicles (SVs) must physically attach to the plasma membrane (termed docking) and must undergo a process termed priming (Verhage and Sorensen, 2008). Docking and priming are both mediated by the SNARE proteins. Primed vesicles are thought to consist of docked SVs containing partially assembled trans-SNARE complexes (Xu et al., 1999). Several SNARE binding proteins regulate SV docking and priming. UNC-10/RIM, UNC-13/Munc13, and UNC-31/ CAPS promote docking and priming while Tomosyn inhibits both processes (Gracheva et al., 2006, 2007, 2008; McEwen et al., 2006; Weimer et al., 2006; Hammarlund et al., 2007). Collectively, these studies suggest that Munc13 (and other priming factors) stimulate exocytosis by promoting SV docking and the initial assembly of trans-SNARE complexes.

SV priming factors are extensively regulated by second messengers (Verhage and Sorensen, 2008). For example, all Munc13 proteins have binding sites for DAG (the $\mathrm{C} 1$ domain), calcium (C2B), and calmodulin (Betz et al., 1998, 2001; Shin et al., 2010; Lipstein et al., 2012). Mutations that block DAG binding to Munc13's C1 domain block potentiation of synaptic transmission by synthetic DAG ligands (phorbol esters; Lackner et al., 1999; Rhee et al., 2002; Basu et al., 2007). Similarly, mutations that block calcium and calmodulin binding to Munc13 alter short-term plasticity (Shin et al., 2010; Lipstein et al., 2013). Thus, treatments altering individual second messengers adjust

\footnotetext{
Received July 11, 2014; revised Nov. 21, 2014; accepted Nov. 26, 2014.

Author contributions: Z.H., A.V.-M., and J.M.K. designed research; Z.H. and A.V.-M. performed research; Z.H., A.V.-M., and J.M.K. analyzed data; Z.H., A.V.-M., and J.M.K. wrote the paper.

This work was supported by a National Institutes of Health research grant (GM54728 to J.K.). We thank members of the Kaplan lab for critical comments on this manuscript. Some strains were provided by the C. elegans Genetics Stock Center.

The authors declare no competing financial interests.

Correspondence should be addressed to Joshua M Kaplan, Department of Molecular Biology, Massachusetts General Hospital-Simches Research Building, 7th Floor, 185 Cambridge Street, Boston MA 02114. E-mail: kaplan@molbio.mgh.harvard.edu.

DOI:10.1523/JNEUROSCI.2825-14.2015

Copyright $\odot 2015$ the authors $\quad 0270-6474 / 15 / 351038-05 \$ 15.00 / 0$
}

Munc13 priming activity and neurotransmitter release. In contrast, endogenous neuromodulators simultaneously activate multiple second messengers. For example, GPCRs activate protein kinases, Rac and Rho GTPases, as well as phospholipases. Thus, natural neuromodulators may have more complex effects than treatments designed to manipulate individual second messengers.

The Caenorhabditis elegans neuromuscular junction (NMJ) has been used as a model to address these questions. Transmission at this synapse is mediated by graded release of ACh, whereby release varies with the strength of depolarization (Liu et al., 2009). When activity is low, transmission consists of mEPSCs that are evoked by fusion of a single SV (Liu et al., 2005), hereafter designated tonic release. Forced depolarization of motor neurons evokes the synchronous release of several hundred SVs. Prior genetic studies suggest that egl-30 G $\alpha_{\mathrm{q}}$ and its target (egl-8 PLC $\beta$ ) enhances transmission at NMJs (Hajdu-Cronin et al., 1999; Lackner et al., 1999; Miller et al., 1999). These studies used behavioral (not electrophysiological) assays; consequently, it remains unclear how egl-30 G $\alpha_{\mathrm{q}}$ and egl-8 PLC $\beta$ alter ACh release.

We previously showed that a neuropeptide (NLP-12) and its receptor (CKR-2) potentiate tonic and evoked ACh release at NMJs (Hu et al., 2011). Here we show that potentiation of evoked release requires activation of egl-30 $\mathrm{G} \alpha$ and $e g l-8$ PLC $\beta$, and that distinct UNC-13 proteins mediate the resulting potentiation of tonic and evoked ACh release.

\section{Materials and Methods}

Strains. Animals were cultivated at $20^{\circ} \mathrm{C}$ on agar nematode growth media seeded with OP50 bacteria. The following strains were used in this study: wild-type N2 bristol, DA1084 egl-30(ad806), JT47 egl-8(sa47), KP6901 unc-13(s69), KP7451 nuEx1677 [Pacr-2::EGL-30];egl-30(ad806), KP7447 nuEx1673 [Pacr-2::EGL-8];egl-8(sa47), KP6893 nuEx1515 [Psnb-1::UNC-13L]; unc-13(s69), KP6899 nuIs46 [Punc-13::UNC13S::GFP];unc-13(s69), KP6893 nuEx1515 [Psnb-1::UNC-13L(H699K)]; unc-13(s69), and KP6899 nuIs52 [Punc-13::UNC-13S(H348K)::GFP]; unc-13(s69). 
Constructs and transgenes. Transgenic strains were isolated by microinjection of various plasmids using either Pmyo-2::NLS-GFP (KP\#1106) or Pmyo-2::NLS-mCherry (KP\#1480) as a coinjection marker. Integrated transgenes were obtained by UV irradiation and were out-crossed at least six times. EGL-30 (M01D7.7a; wormbase.org) or EGL-8 (B0348.4a; wormbase.org) cDNAs were expressed in cholinergic motor neurons using the acr-2 promoter.

Locomotion assays. For aldicarb paralysis, between 18 and 25 young adult worms were transferred to plates containing $1.5 \mathrm{~mm}$ aldicarb and assayed for paralysis as described previously (Nurrish et al., 1999).

Electrophysiology. Electrophysiology was done on dissected adults as previously described (Richmond and Jorgensen, 1999; Hu et al., 2011, 2013). For aldicarb exposure, a single adult was transferred to a plate containing $1 \mathrm{~mm}$ aldicarb for $60 \mathrm{~min}$ before the dissection. Statistical significance was determined using a two-tailed Student's $t$ test.

\section{Results}

Aldicarb potentiation of release is decreased in egl-30 $\mathrm{G} \alpha_{\mathrm{q}}$ and egl-8 PLC $\beta$ mutants

The effects of NLP-12 on release are assessed by recording EPSCs following treatment with a cholinesterase inhibitor, aldicarb $(\mathrm{Hu}$ et al., 2011). Aldicarb induces body muscle contraction, which enhances NLP-12 secretion from a stretch sensing neuron (DVA; $\mathrm{Hu}$ et al., 2011). Following aldicarb treatment, the mEPSC rate and the total synaptic charge of evoked responses were both approximately doubled (Fig. $1 A, B, D-F$ ). The effects of aldicarb on tonic and evoked release are eliminated in mutants lacking NLP-12 and in those lacking an NLP-12 receptor (CKR-2; Hu et al., 2011).

CKR-2 receptors are coupled to G-proteins containing a G $\alpha_{\mathrm{q}^{-}}$ subunit (Janssen et al., 2008). Consequently, we tested the idea that egl-30 $\mathrm{G} \alpha$ and $e g l-8$ PLC $\beta$ are required for aldicarb-induced potentiation. The aldicarb-induced increase in evoked synaptic charge was eliminated in both egl-30 $\mathrm{G} \alpha_{\mathrm{q}}$ and egl-8 PLC $\beta$ mutants, and this defect was rescued by constructs expressing the corresponding genes in cholinergic motor neurons (using the acr-2 promoter; Fig. $1 A, B)$. Similarly, restoring egl-30 $\mathrm{G} \alpha_{\mathrm{q}}$ and egl-8 PLC $\beta$ expression in motor neurons rescued mutant defects in aldicarb-induced paralysis (Fig. 1C). Thus, egl-30 $\mathrm{G} \alpha$ and egl-8 PLC $\beta$ are required for aldicarb-induced potentiation of evoked ACh release, as would be predicted if the NLP-12 receptor (CKR-2) was coupled to $\mathrm{G}_{\mathrm{q}}$ (Janssen et al., 2008). Interestingly, the aldicarb-induced increase in mEPSC rate was only modestly reduced in egl-30 G $\alpha_{\mathrm{q}}$ mutants and was unaffected in egl-8 PLC $\beta$ mutants (Fig. $1 D-F$ ), implying that distinct mechanisms mediate NLP-12 potentiation of tonic and evoked release.

To further investigate EGL-30's role in tonic release, we analyzed eat-16 RGS mutants (Fig. 2). EAT-16 has GTPase-activating activity for EGL-30 G $\alpha_{\mathrm{q}}$ (Hajdu-Cronin et al., 1999); consequently, eat-16 mutants can be used to assess the effects of enhanced EGL-30 activity. In eat-16 mutants, mEPSC rates were significantly increased (Fig. $2 A, B$ ). This effect was abolished in egl-30 eat-16 double mutants (Fig. 2A,B). Thus, increased EGL-30 G $\alpha_{\mathrm{q}}$ activity produces a corresponding increase in tonic release.

EGL-30 G $\alpha_{\mathrm{q}}$ is required for synaptic potentiation by NLP-12 NLP-12 and EGL-30 G $\alpha$ are both required for synaptic potentiation by aldicarb, consistent with the idea that NLP-12 potentiates release via activation of EGL-30. We did two further experiments to test this idea. First, we analyzed tonic release in nlp-12 eat-16 and eat-16; $c k r-2$ double mutants. The enhanced mEPSC rate exhibited by eat-16 single mutants was significantly reduced in both $n l p-12$ eat-16 and eat-16; $c k r-2$ double mutants

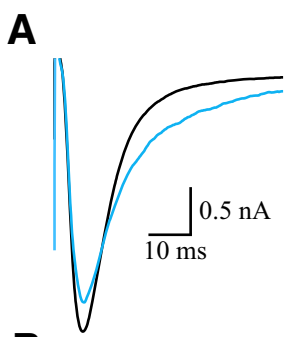

B

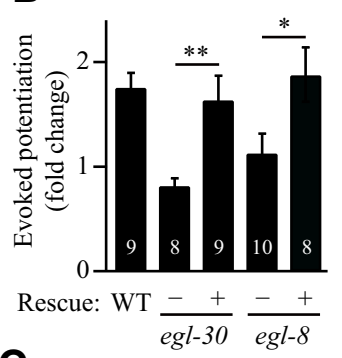

C

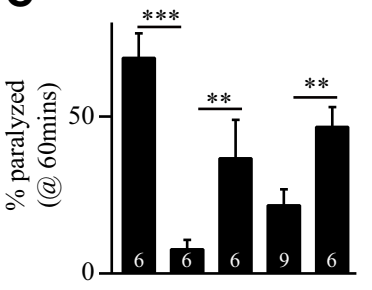

Rescue: WT $\frac{-+}{e g l-30} \frac{-+}{\text { egl-8}}$

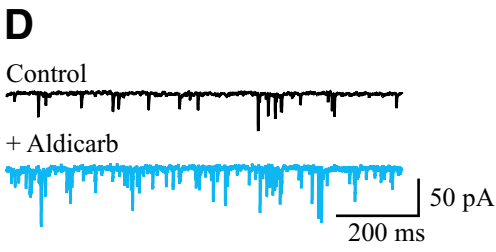

$\longrightarrow$ Control $\longrightarrow$ Aldicarb

E

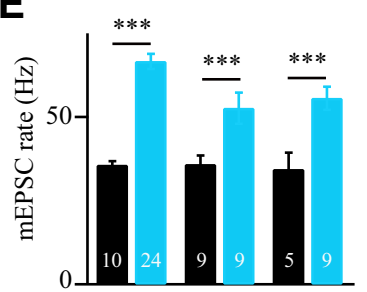

Aldicarb:

$\mathbf{F}$

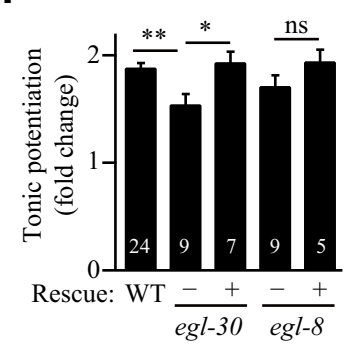

Figure 1. $\mathrm{EGL}-30 / \mathrm{G} \alpha$ and $\mathrm{EGL}-8 / \mathrm{PLC} \beta$ are required for aldicarb-induced potentiation of evoked release. Mutations inactivating EGL-30/G $\alpha$ and EGL-8/PLC $\beta$ prevent aldicarb potentiation of evoked $A C h$ release but have little effect on potentiation of tonic release. Evoked EPSCS $(\boldsymbol{A}, \boldsymbol{B})$ and mEPSCs (D-F) were recorded from adult body wall muscle, with (blue) and without (black) a 60 min aldicarb treatment. Averaged evoked EPSCs $(\boldsymbol{A})$ and representative mEPSC traces $(\boldsymbol{D})$ are shown. Summary data for evoked $(\boldsymbol{B})$ and tonic $(\boldsymbol{E}, \boldsymbol{F})$ release are shown for wild-type, egl-30, and egl-8 mutants. Rescue indicates mutant animals containing a transgene expressing the indicated gene in cholinergic motor neurons. $\boldsymbol{C}$, Aldicarb-induced paralysis is compared for the indicated genotypes. Statistically significant differences $\left({ }^{* * *} p<0.001\right.$, ${ }^{* *} p<0.01,{ }^{*} p<0.05$, and ns not significant), the number of animals analyzed $(\boldsymbol{B}, \boldsymbol{E}, \boldsymbol{F})$, and the number of replicate experiments $(\boldsymbol{C})$ are indicated. Error bars indicate $S E M$.

(Fig. $2 A, B$ ). The mEPSC rate of $n l p-12$ and $c k r-2$ single mutants is indistinguishable from wild-type controls (Hu et al., 2011). Thus, inactivating NLP-12 and CKR-2 decreased mEPSC rate only when EGL-30 G $\alpha_{\mathrm{q}}$ activity was enhanced (in eat-16 mutants). Second, we analyzed aldicarb-induced paralysis of double mutants. As previously reported, both $c k r-2$ and egl-30 single mutants are resistant to aldicarb-induced paralysis; however, additive effects on aldicarb sensitivity were not observed in egl30; $c k r-2$ double mutants (Fig. 2C). Together, these results support the idea the NLP-12, CKR-2, and EGL-30 G $\alpha_{\mathrm{q}}$ act together to potentiate ACh release.

Aldicarb-potentiated tonic release is mediated by UNC-13L Activation of EGL- 8 PLC $\beta$ stimulates PIP $_{2}$ hydrolysis, producing the second messengers DAG and IP3. Prior studies suggested that DAG binding to UNC-13/Munc13 promotes ACh release in C. elegans and glutamate release in rodent neurons (Lackner et al., 1999; Rhee et al., 2002). For this reason, we tested the idea that $\mathrm{UNC}-13$ is required for aldicarb-induced potentiation of $\mathrm{ACh}$ release.

The unc-13 gene encodes two isoforms (UNC-13S and L), which have different $\mathrm{N}$-terminal domains but share a 1200 aa 
A

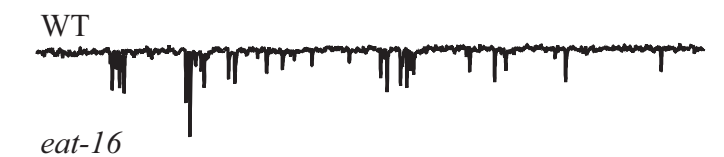

71, r egl-30 eat -16

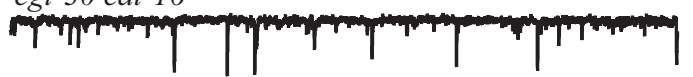

nlp-12 eat-16
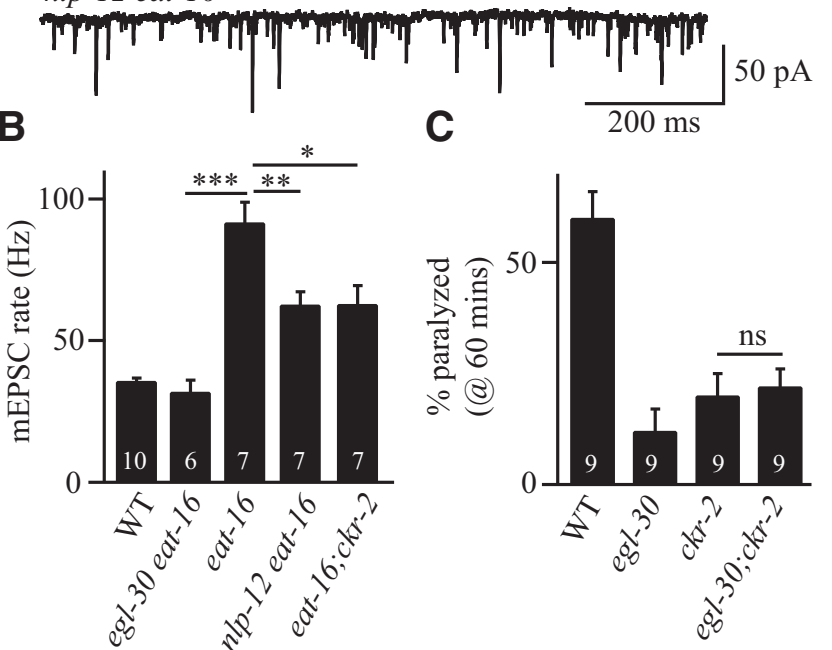

Figure 2. Increased EGL-30 $\mathrm{G} \alpha_{\mathrm{q}}$ activity enhanced tonic release. $\boldsymbol{A}, \boldsymbol{B}$, The eat-16 RGS mutants have enhanced EGL-30 activity (Hajdu-Cronin et al., 1999) and a corresponding increase in $\mathrm{mEPSC}$ rate. This effect was abolished in egl-30 mutants, and was diminished in $n / p-12$ and ckr-2 mutants. Representative traces $(\boldsymbol{A})$ and summary data $(\boldsymbol{B})$ for mEPSCs are shown. $\boldsymbol{C}$, The egl-30 and $\mathrm{ckr}-2$ single mutants were both resistant to aldicarb-induced paralysis but double mutants did not exhibit additive defects. These results suggest that NLP-12 stimulates ACh release by activating EGL-30. Statistically significant differences $\left({ }^{* * *} p<0.001\right.$, ${ }^{* *} p<0.01$, ${ }^{*} p<0.05$, and $\mathrm{ns}$, not significant), the number of animals analyzed $(\boldsymbol{B})$, and the number of replicate experiments $(\boldsymbol{C})$ are indicated. Error bars indicate SEM.

C-terminal domain (Kohn et al., 2000; Hu et al., 2013). To determine which UNC-13 protein is required for NLP-12's effects on tonic release, we analyzed aldicarb potentiation of $\mathrm{mEPSC}$ rate in unc-13(s69) mutants that express either UNC-13L or S transgenes (Fig. 3). Aldicarb-treatment increased the mEPSC rate of UNC-13L-rescued animals and wild-type controls to similar levels, and this effect was eliminated by a mutation $(\mathrm{H} 699 \mathrm{~K})$ that disrupts DAG binding to UNC-13L (Fig. 3A-C; Betz et al., 1998). In contrast, aldicarb had no effect on the mEPSC rate of UNC13S-rescued animals (Fig. 3A-C). Thus, NLP-12's effects on tonic release require DAG binding to UNC-13L.

\section{Aldicarb potentiates evoked release mediated by both UNC- $13 \mathrm{~L}$ and $\mathrm{S}$}

Which UNC-13 protein potentiates evoked release? Transgenes expressing either UNC-13S or UNC-13L partially rescue the baseline-evoked EPSC defect of unc-13(s69) mutants (Fig. 4A, B), consistent with our prior study (Hu et al., 2013). Partial rescue is expected because the wild type-evoked response is a composite of both UNC-13S and UNC-13L-mediated release (Hu et al., 2013). Aldicarb potentiation of evoked release in UNC-13S- and UNC13L-rescued animals was similar to that in wild-type controls (Fig. 4A-C). Potentiation of evoked responses was eliminated by $\mathrm{C} 1$ domain mutations that disrupt DAG binding to UNC-13S
A
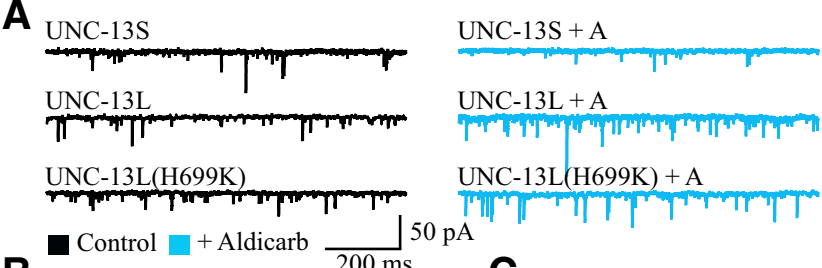

B
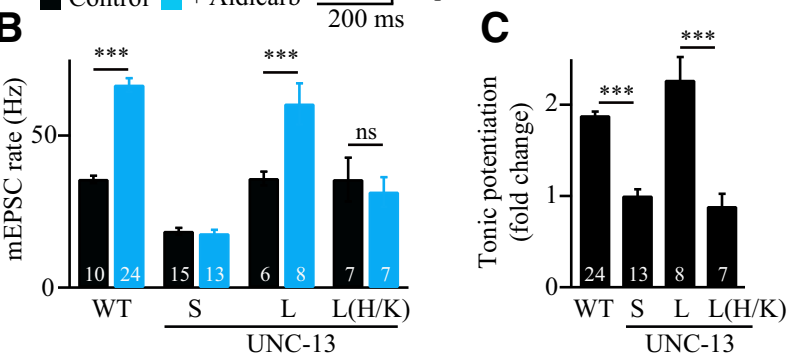

Figure 3. Aldicarb potentiation of tonic release required DAG binding to UNC-13L but not UNC-13S. Aldicarb potentiated tonic release in animals expressing UNC-13L but not in those expressing UNC-13S. Potentiation of tonic release was blocked by a mutation that prevents DAG binding to UNC-13L (H699K). UNC-13S or UNC-13L transgenes were expressed in unc-13(s69) mutants. mEPSCs were recorded from adult body wall muscle of the indicated genotypes, with (blue) and without (black) a 60 min aldicarb treatment. Representative traces $(\boldsymbol{A})$, average $m E P S C$ rates $(\boldsymbol{B})$, and aldicarb potentiation of $m E P S C$ rates $(\boldsymbol{C})$ are shown. Statistically significant differences $\left({ }^{* *} p<0.001\right.$ and $n s$, not significant) and the number of animals analyzed are indicated. Error bars indicate SEM.

A

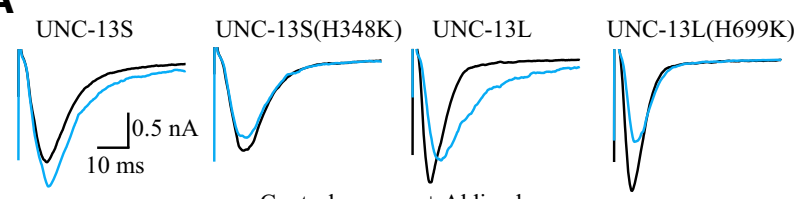

B

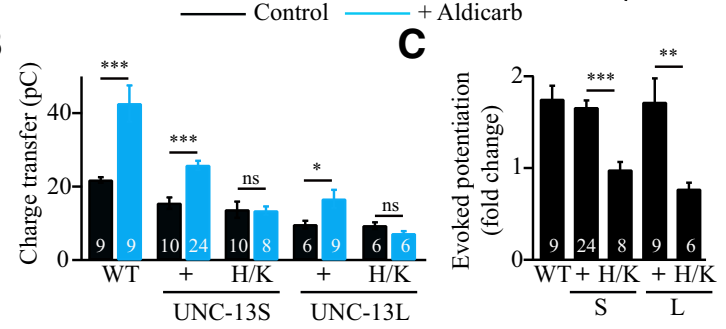

D

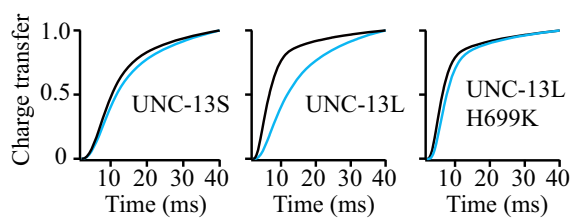

Figure 4. DAG binding to UNC-13S and L potentiated evoked release. Aldicarb-potentiated evoked release was analyzed in animals expressing UNC-13S or UNC-13L. For both UNC-13 proteins, potentiation of evoked release was blocked by mutations that prevent DAG binding. UNC-13 transgenes were expressed in unc-13(s69) mutants. Averaged evoked responses $(\boldsymbol{A})$ and summary data $(\boldsymbol{B}, \boldsymbol{C})$ are shown. $\boldsymbol{D}$, The time course of charge transfer during evoked responses is compared. The number of animals analyzed is indicated for each genotype. Statistically significant differences ( ${ }^{* * *} p<0.001,{ }^{* *} p<0.01,{ }^{*} p<0.05$, and ns, not significant) and the number of animals analyzed are indicated. Error bars indicate SEM.

(H348K) or UNC-13L (H699K; Betz et al., 1998; Nurrish et al., 1999; Fig. 4A-C). Thus, NLP-12 potentiates evoked release via DAG binding to both UNC-13 proteins.

We previously showed that the kinetics of evoked release mediated by UNC-13L is faster than that mediated by UNC-13S ( Hu et al., 2013). To determine whether aldicarb alters release kinet- 
ics, we analyzed the charge transfer kinetics of evoked responses. Aldicarb treatment significantly slowed the charge transfer of UNC-13L-mediated evoked responses and this effect was eliminated by the UNC-13L(H699K) mutation (Fig. 4D). In contrast, aldicarb had no effect on the kinetics of UNC-13S-mediated evoked responses (Fig. 4D). These results suggest that DAG binding to UNC-13L slows ACh release during evoked responses.

\section{Discussion}

Here we show that NLP-12 stimulates ACh release via DAG binding to UNC-13S and UNC-13L. These results identify an endogenous neuromodulator that potentiates release through the PLC $\beta /$ UNC-13 pathway. UNC-13/Munc13 proteins have been implicated in phorbol ester effects on secretion and in several forms of short-term plasticity. Our results suggest that GPCRs coupled to $\mathrm{G} \alpha_{\mathrm{q}}$, and in particular neuropeptide receptors, potentiate transmission through changes in DAG liganding of UNC13. Consistent with this idea, CCK has been shown to stimulate glutamate release in hippocampal neurons via a $\mathrm{G} \alpha_{\mathrm{q}}$-coupled receptor (Breukel et al., 1997; Deng et al., 2010). Because the NLP-12 receptor (CKR-2) is most similar to mammalian CCK receptors (Janssen et al., 2008), our results suggest that potentiation of neurotransmitter release by NLP-12/CCK-like neuropeptides is ancient and likely acts via changes in UNC-13 activity. Neuropeptides are broadly expressed in the brain in both vertebrate and invertebrate animals. Consequently, neuropeptide regulation of UNC-13/Munc13 proteins provides a potential mechanism for modulating circuit function and behavioral states.

Prior studies showed that different Munc13 isoforms mediate different forms of short-term plasticity in rodent neurons (Rosenmund et al., 2002). Following high-frequency stimulus trains, synapses relying on Munc13-1 are depressed whereas those using Munc13-2 are potentiated. UNC-13 proteins containing the C2A domain (UNC-13L, Munc13-1, and ubMunc13-2) mediate a fast form of release whereas UNC-13 proteins lacking the C2A domain (UNC-13S and bMunc13-2) mediate slow release (Chen et al., 2013; Hu et al., 2013; Zhou et al., 2013). Thus, differential expression of Munc13 isoforms endows synapses with different patterns of release, and different forms of plasticity.

Here we extend these studies by showing that NLP-12 potentiates tonic and evoked ACh release by distinct mechanisms. In particular, our results indicate that different UNC-13 isoforms regulate tonic (UNC-13L) and evoked (both UNC-13L and S) release. These results provide genetic evidence that neuromodulators engage different UNC-13 proteins to regulate different forms of release.

Aldicarb caused UNC-13L-mediated evoked release to become significantly slower and more prolonged, whereas it had no effect on UNC-13S release kinetics. These results suggest that DAG binding to UNC-13L loosens the coupling of primed SVs to the calcium channel driving release. This could be mediated by altered binding of UNC-13L to UNC-10/RIM or by changes in the kinetics of calcium binding to UNC-13L primed SVs. Further experiments are required to distinguish between these possibilities. These results suggest that neuromodulators like NLP-12 provide a means to adjust release kinetics.

NLP-12 potentiation of tonic and evoked release also differed in their sensitivity to egl-30 $\mathrm{G} \alpha_{\mathrm{q}}$ and egl-8 PLC $\beta$ mutations. The egl-30(ad106) mutation is a partial loss of function; consequently, residual aldicarb potentiation of tonic release in this mutant could be mediated by residual EGL-30 activity. It is not possible to test the effect of egl-30-null mutations, as these mutants are not viable (Brundage et al., 1996). Alternatively, the residual poten- tiation of tonic release in egl-30 mutants could be mediated by other $\mathrm{G} \alpha$-subunits. Further experiments are required to distinguish between these possibilities. DAG binding to UNC-13L is required for potentiation of tonic release, as this effect is blocked by the UNC-13L (H699K) mutation. Nonetheless, EGL-8 PLC $\beta$ null mutations had no effect on aldicarb-induced potentiation of mEPSC rate. These results imply that DAG produced by other phospholipases potentiates tonic release.

How are tonic and evoked release differentially regulated? Aldicarb potentiates tonic release mediated by UNC-13L but not by UNC-13S. UNC-13L has a C2A domain that is absent in UNC$13 S$ (Kohn et al., 2000; Hu et al., 2013). The C2A domain binds UNC-10/RIM (Lu et al., 2006), localizing UNC-13L to the center of the active zone (adjacent to the dense projection; Weimer et al., 2006). UNC-13 proteins lacking C2A exhibit a more diffuse presynaptic distribution (Chen et al., 2013; Hu et al., 2013; Zhou et al., 2013). RIM proteins bind voltage-activated calcium channels ( $\mathrm{CaVs}$ ) thereby concentrating $\mathrm{CaV}$ channels at active zones (Han et al., 2011; Kaeser et al., 2011; Graf et al., 2012; Müller et al., 2012). Thus, our results suggest that aldicarb selectively promotes tonic release of SVs that are adjacent to presynaptic $\mathrm{CaV}$ channels.

Several prior studies support the idea that different forms of release are mediated by distinct sets of synaptic proteins. Mouse DOC2 is required for spontaneous but not evoked neurotransmitter release (Groffen et al., 2010; Pang et al., 2011). Inactivating synaptotagmin I or complexin decreases synchronous-evoked release but enhances spontaneous neurotransmitter release (DiAntonio and Schwarz, 1994; Littleton et al., 1994; Pang et al., 2006; Hobson et al., 2011; Martin et al., 2011). Collectively, these results suggest that the different patterns of release and different forms of synaptic plasticity are dictated by the expression and function of distinct synaptic proteins.

\section{References}

Basu J, Betz A, Brose N, Rosenmund C (2007) Munc13-1 C1 domain activation lowers the energy barrier for synaptic vesicle fusion. J Neurosci 27:1200-1210. CrossRef Medline

Betz A, Ashery U, Rickmann M, Augustin I, Neher E, Südhof TC, Rettig J, Brose N (1998) Munc13-1 is a presynaptic phorbol ester receptor that enhances neurotransmitter release [in process citation]. Neuron 21:123136. CrossRef Medline

Betz A, Thakur P, Junge HJ, Ashery U, Rhee JS, Scheuss V, Rosenmund C, Rettig J, Brose N (2001) Functional interaction of the active zone proteins Munc13-1 and RIM1 in synaptic vesicle priming. Neuron 30:183196. CrossRef Medline

Breukel AI, Lopes da Silva FH, Ghijsen WE (1997) Cholecystokinin (CCK-8) modulates vesicular release of excitatory amino acids in rat hippocampal nerve endings. Neurosci Lett 234:67-70. CrossRef Medline

Brundage L, Avery L, Katz A, Kim U-J, Mendel JE, Sternberg PW, Simon MI (1996) Mutations in a C. elegans Gqa gene disrupt movement, egg laying, and viability. Neuron 16:999-1009. CrossRef Medline

Chen Z, Cooper B, Kalla S, Varoqueaux F, Young SM Jr (2013) The Munc13 proteins differentially regulate readily releasable pool dynamics and calcium-dependent recovery at a central synapse. J Neurosci 33:83368351. CrossRef Medline

Deng PY, Xiao Z, Jha A, Ramonet D, Matsui T, Leitges M, Shin HS, Porter JE, Geiger JD, Lei S (2010) Cholecystokinin facilitates glutamate release by increasing the number of readily releasable vesicles and releasing probability. J Neurosci 30:5136-5148. CrossRef Medline

DiAntonio A, Schwarz TL (1994) The effect on synaptic physiology of synaptotagmin mutations in Drosophila. Neuron 12:909-920. CrossRef Medline

Gracheva EO, Burdina AO, Holgado AM, Berthelot-Grosjean M, Ackley BD, Hadwiger G, Nonet ML, Weimer RM, Richmond JE (2006) Tomosyn inhibits synaptic vesicle priming in Caenorhabditis elegans. PLoS Biol 4:e261. CrossRef Medline 
Gracheva EO, Burdina AO, Touroutine D, Berthelot-Grosjean M, Parekh H, Richmond JE (2007) Tomosyn negatively regulates CAPS-dependent peptide release at Caenorhabditis elegans synapses. J Neurosci 27:1017610184. CrossRef Medline

Gracheva EO, Hadwiger G, Nonet ML, Richmond JE (2008) Direct interactions between C. elegans RAB-3 and Rim provide a mechanism to target vesicles to the presynaptic density. Neurosci Lett 444:137-142. CrossRef Medline

Graf ER, Valakh V, Wright CM, Wu C, Liu Z, Zhang YQ, DiAntonio A (2012) RIM promotes calcium channel accumulation at active zones of the Drosophila neuromuscular junction. J Neurosci 32:16586-16596. CrossRef Medline

Groffen AJ, Martens S, Diez Arazola R, Cornelisse LN, Lozovaya N, de Jong AP, Goriounova NA, Habets RL, Takai Y, Borst JG, Brose N, McMahon HT, Verhage M (2010) Doc2b is a high-affinity Ca2+ sensor for spontaneous neurotransmitter release. Science 327:1614-1618. CrossRef Medline

Hajdu-Cronin YM, Chen WJ, Patikoglou G, Koelle MR, Sternberg PW (1999) Antagonism between g(o)alpha and g(q)alpha in Caenorhabditis elegans: the RGS protein EAT-16 is necessary for $\mathrm{g}(\mathrm{o})$ alpha signaling and regulates $\mathrm{g}(\mathrm{q})$ alpha activity [in process citation]. Genes Dev 13:17801793. CrossRef Medline

Hammarlund M, Palfreyman MT, Watanabe S, Olsen S, Jorgensen EM (2007) Open syntaxin docks synaptic vesicles. PLoS Biol 5:e198. CrossRef Medline

Han Y, Kaeser PS, Südhof TC, Schneggenburger R (2011) RIM determines $\mathrm{Ca}(2)+$ channel density and vesicle docking at the presynaptic active zone. Neuron 69:304-316. CrossRef Medline

Hobson RJ, Liu Q, Watanabe S, Jorgensen EM (2011) Complexin maintains vesicles in the primed state in C. elegans. Curr Biol 21:106-113. CrossRef Medline

Hu Z, Pym EC, Babu K, Vashlishan Murray AB, Kaplan JM (2011) A neuropeptide-mediated stretch response links muscle contraction to changes in neurotransmitter release. Neuron 71:92-102. CrossRef Medline

Hu Z, Tong XJ, Kaplan JM (2013) UNC-13L, UNC-13S, and Tomosyn form a protein code for fast and slow neurotransmitter release in Caenorhabditis elegans. eLife 2:e00967. CrossRef Medline

Janssen T, Meelkop E, Lindemans M, Verstraelen K, Husson SJ, Temmerman L, Nachman RJ, Schoofs L (2008) Discovery of a cholecystokiningastrin-like signaling system in nematodes. Endocrinology 149:28262839. CrossRef Medline

Kaeser PS, Deng L, Wang Y, Dulubova I, Liu X, Rizo J, Südhof TC (2011) RIM proteins tether $\mathrm{Ca} 2+$ channels to presynaptic active zones via a direct PDZ-domain interaction. Cell 144:282-295. CrossRef Medline

Kohn RE, Duerr JS, McManus JR, Duke A, Rakow TL, Maruyama H, Moulder G, Maruyama IN, Barstead RJ, Rand JB (2000) Expression of multiple UNC-13 proteins in the C. elegans nervous system. Mol Biol Cell 11:34413452. CrossRef Medline

Lackner MR, Nurrish SJ, Kaplan JM (1999) Facilitation of synaptic transmission by EGL-30 G $\alpha$ q and EGL-8 Phospholipase C $\beta$ : DAG-binding to UNC-13 is required to stimulate acetylcholine release. Neuron 24:335346. CrossRef Medline

Lipstein N, Schaks S, Dimova K, Kalkhof S, Ihling C, Kölbel K, Ashery U, Rhee J, Brose N, Sinz A, Jahn O (2012) Non-conserved Ca2+/calmodulin binding sites in Munc13s differentially control synaptic short-term plasticity. Mol Cell Biol 32:4628-4641. CrossRef Medline

Lipstein N, Sakaba T, Cooper BH, Lin KH, Strenzke N, Ashery U, Rhee JS, Taschenberger H, Neher E, Brose N (2013) Dynamic control of synaptic vesicle replenishment and short-term plasticity by Ca-calmodulinMunc13-1 signaling. Neuron 79:82-96. CrossRef Medline
Littleton JT, Stern M, Perin M, Bellen HJ (1994) Calcium dependence of neurotransmitter release and rate of spontaneous vesicle fusions are altered in Drosophila synaptotagmin mutants. Proc Natl Acad Sci U S A 91:10888-10892. CrossRef Medline

Liu Q, Chen B, Yankova M, Morest DK, Maryon E, Hand AR, Nonet ML, Wang ZW (2005) Presynaptic ryanodine receptors are required for normal quantal size at the Caenorhabditis elegans neuromuscular junction. J Neurosci 25:6745-6754. CrossRef Medline

Liu Q, Hollopeter G, Jorgensen EM (2009) Graded synaptic transmission at the Caenorhabditis elegans neuromuscular junction. Proc Natl Acad Sci U S A 106:10823-10828. CrossRef Medline

Lu J, Machius M, Dulubova I, Dai H, Südhof TC, Tomchick DR, Rizo J (2006) Structural basis for a Munc13-1 homodimer to Munc13-1/RIM heterodimer switch. PLoS Biol 4:e192. CrossRef Medline

Martin JA, Hu Z, Fenz KM, Fernandez J, Dittman JS (2011) Complexin has opposite effects on two modes of synaptic vesicle fusion. Curr Biol 21:97105. CrossRef Medline

McEwen JM, Madison JM, Dybbs M, Kaplan JM (2006) Antagonistic Regulation of Synaptic Vesicle Priming by Tomosyn and UNC-13. Neuron 51:303-315. CrossRef Medline

Miller KG, Emerson MD, Rand JB (1999) Goalpha and diacylglycerol kinase negatively regulate the Gqalpha pathway in C. elegans [see comments]. Neuron 24:323-333. CrossRef Medline

Müller M, Liu KS, Sigrist SJ, Davis GW (2012) RIM Controls Homeostatic Plasticity through Modulation of the Readily-Releasable Vesicle Pool. J Neurosci 32:16574-16585. CrossRef Medline

Nurrish S, Ségalat L, Kaplan JM (1999) Serotonin inhibition of synaptic transmission: GOA-1 decreases the abundance of UNC-13 at release sites. Neuron 24:231-242. CrossRef Medline

Pang ZP, Sun J, Rizo J, Maximov A, Südhof TC (2006) Genetic analysis of synaptotagmin 2 in spontaneous and Ca2+-triggered neurotransmitter release. EMBO J 25:2039-2050. CrossRef Medline

Pang ZP, Bacaj T, Yang X, Zhou P, Xu W, Südhof TC (2011) Doc2 supports spontaneous synaptic transmission by a $\mathrm{Ca}(2+)$-independent mechanism. Neuron 70:244-251. CrossRef Medline

Rhee JS, Betz A, Pyott S, Reim K, Varoqueaux F, Augustin I, Hesse D, Südhof TC, Takahashi M, Rosenmund C, Brose N (2002) Beta phorbol esterand diacylglycerol-induced augmentation of transmitter release is mediated by Munc13s and not by PKCs. Cell 108:121-133. CrossRef Medline

Richmond JE, Jorgensen EM (1999) One GABA and two acetylcholine receptors function at the C. elegans neuromuscular junction. Nat Neurosci 2:791-797. CrossRef Medline

Rosenmund C, Sigler A, Augustin I, Reim K, Brose N, Rhee JS (2002) Differential control of vesicle priming and short-term plasticity by Munc13 isoforms. Neuron 33:411-424. CrossRef Medline

Shin OH, Lu J, Rhee JS, Tomchick DR, Pang ZP, Wojcik SM, Camacho-Perez M, Brose N, Machius M, Rizo J, Rosenmund C, Südhof TC (2010) Munc13 C2B domain is an activity-dependent $\mathrm{Ca} 2+$ regulator of synaptic exocytosis. Nat Struct Mol Biol 17:280-288. CrossRef Medline

Verhage M, Sørensen JB (2008) Vesicle docking in regulated exocytosis. Traffic 9:1414-1424. CrossRef Medline

Weimer RM, Gracheva EO, Meyrignac O, Miller KG, Richmond JE, Bessereau JL (2006) UNC-13 and UNC-10/rim localize synaptic vesicles to specific membrane domains. J Neurosci 26:8040-8047. CrossRef Medline

Xu T, Rammner B, Margittai M, Artalejo AR, Neher E, Jahn R (1999) Inhibition of SNARE complex assembly differentially affects kinetic components of exocytosis. Cell 99:713-722. CrossRef Medline

Zhou K, Stawicki TM, Goncharov A, Jin Y (2013) Position of UNC-13 in the active zone regulates synaptic vesicle release probability and release kinetics. eLife 2:e01180. CrossRef Medline 